http://dx.doi.org/10.18778/1429-3730.49.06

Mgr Anna Wiśniewska*

\title{
OCENA ROZWOJU TURYSTYKI ZRÓWNOWAŻONEJ W POLSKICH REGIONACH
}

\author{
SUSTAINABLE TOURISM DEVELOPMENT APPRAISAL IN VARIOUS \\ REGIONS OF POLAND
}

\begin{abstract}
Tourism has its functions and dysfunctions for the reception region. The purpose of the study is to state which of Polish regions can be characterized as the areas of sustainable tourism reception. To achieve the aim of the study the following hypothesis was put forward: voivodships of northern and southern Poland were the areas of sustainable tourism reception in 2015. The examination of the sustainable tourism should take into consideration both positive and negative influence of tourism on the environment and society; that is why the taxonomic measure of development was employed. The study included variables concerning tourism directly as well as those connected indirectly with its development in the given area. Regarding the substantive criteria of variables' selection the author considered the state of the art in tourism and economic sciences. The conducted research indicated that some of regions in Poland can be recognized as the sustainable tourism reception regions.
\end{abstract}

Keywords: sustainable tourism, tourism in Poland, tourism reception regions, the taxonomic measure of development

JEL classification: C38, Q01, Z32

* Uniwersytet Mikołaja Kopernika w Toruniu, Wydział Nauk Ekonomicznych i Zarządzania, Katedra Doskonałości Biznesowej, amw@doktorant.umk.pl 


\section{Wprowadzenie}

Istniejące dysfunkcje turystyki sprowokowały badaczy do poszukiwania rozwiązań problemów pojawiających się w wyniku rozwoju turystyki masowej. Funkcje i dysfunkcje turystyki można rozpatrywać w kategoriach ekonomicznych, społecznych, politycznych, przyrodniczych czy urbanizacyjnych ${ }^{1}$. Ponadto ten obszar działalności gospodarczej wpływa pośrednio i bezpośrednio na rozwój innych branż, a także oddziałuje na wiele aspektów życia ludzkiego.

Intensywny rozwój turystyki masowej nie ominął również Polski. Jednym z problemów, z którymi muszą zmagać się władze samorządów terytorialnych, jest kwestia zasadności rozwoju turystyki (w określonej formie lub w ogóle) na danym obszarze w kontekście potencjalnych szkód z tego wynikających. Stąd rozważania nad turystyką zrównoważoną na obszarach znanych polskich destynacji turystycznych są uzasadnione. Zrealizowanie celu badawczego, którym jest ustalenie, na obszarze których polskich województw turystyka najlepiej spełnia kryteria zrównoważonego rozwoju, nastąpiło przez weryfikację hipotezy, która brzmi: „Obszarami recepcji turystyki zrównoważonej w 2015 roku były województwa położone na północy i południu Polski”. W artykule zastosowano taksonomiczny miernik rozwoju oraz analizę skupien.

Koncepcja turystyki zrównoważonej wywodzi się z koncepcji wzrostu zrównoważonego, czyli takiego, który „,zaspokaja potrzeby współczesnych mieszkańców i gwarantuje zaspokojenie potrzeb przyszłych pokoleń" ${ }^{2}$. Ta prosta definicja implikuje jednak problem niedookreślenia, co składa się na kwestie zrównoważonego rozwoju, jak trafnie zauważa P. Cegliński ${ }^{3}$ Problem ten występuje również w przypadku koncepcji turystyki zrównoważonej. L. Butowski podkreśla słabą podstawę teoretyczną koncepcji oraz mnogość poglądów prezentowanych przez naukowców, którzy często zajmują się jedynie opisowym wskazywaniem związków między tą ideą a poszczególnymi rodzajami turystyki ${ }^{4}$. Niektórzy badacze (np. B. Mastalska-Cetera i B. Warczewska) wiążą tę koncepcję jedynie z ekologią i poszanowaniem środowiska naturalnego $0^{5}$, czyli utożsamiają turystykę zrównowa-

${ }^{1}$ K. Naumowicz, Podstawowe zagadnienia turystyki, s. 17, http://www.academia.edu/4568029/ Prof._PWSZ_dr_hab._Krystyna_Naumowicz_PODSTAWOWE_ZAGADNIENIA_TURYSTYKILITERATURA_DODATKOWĀ (dostęp: 11.01.2016).

${ }^{2}$ M. Mika, Przemiany pod wptywem turystyki na obszarach recepcji turystycznej, [w:] W. Kurek (red.), Turystyka, Wydawnictwo Naukowe PWN, Warszawa 2008, s. 473.

${ }^{3}$ P. Cegliński, Kwestie zrównoważonego rozwoju w strategiach przedsiębiorstw, „Studia i Prace Wydziału Nauk Ekonomicznych i Zarządzania” 2015, nr 40, t. 2, s. 24, DOI: 10.18276/ sip.2015.40/2-02.

${ }^{4}$ L. Butowski, Dlugookresowy model turystyki zrównoważonej, „Zeszyty Naukowe Uczelni Vistula" 2013, nr 32, s. 6.

${ }^{5}$ B. Mastalska-Cetera, B. Warczewska, Możliwości rozwoju turystyki zrównoważonej na przykładzie dolnośląskich parków krajobrazowych, „Prace Naukowe Uniwersytetu Ekonomicznego we Wrocławiu" 2015, nr 397, s. 33. 
żoną z ekoturystyką. K. Pieńkos i K. Podleśna-Dudicz zwracają uwagę, że to właśnie konieczność ochrony przyrody legła u podstaw stworzenia koncepcji przedstawianej i rozwijanej później przez takie organizacje, jak Światowa Organizacja Turystyki czy Światowa Rada Podróży i Turystyki ${ }^{6}$. Inni, jak M. Kazimierczak, podkreślają konieczność zadbania o lokalną kulturę i kwestie społeczne, gdyż lokalna społeczność powinna być w stanie „zaabsorbować turystykę bez kreowania wewnętrznej dysharmonii społecznej"7. Definicja turystyki zrównoważonej przedstawiona przez A. Kowalczyka podkreśla, że jest to „turystyka mająca niewielki wpływ na środowisko przyrodnicze, chroniąca miejscową kulturę i wspierająca rozwój lokalny"». J. Uglis i A. Jęczmyk zwracają uwagę, że obszar zrównoważonego rozwoju obejmuje nie tylko poszanowanie potrzeb społecznych czy ekologicznych, ale również ekonomicznych'.

Jak trafnie zauważa M. Mika, koncepcja turystyki zrównoważonej nie powinna opisywać stanu idealnego, gdyż osiągnięcie go jest niemożliwe. Podkreślił on również procesowy charakter zjawiska oraz konieczność uwzględniania panujących lokalnie warunków ${ }^{10}$. A. Niezgoda wskazuje, że celami turystyki zrównoważonej są między innymi: zachowanie zasobów środowiska przyrodniczego, stworzenie i utrzymanie przewagi konkurencyjnej obszaru recepcji turystycznej, a także poprawa jakości życia mieszkańców ${ }^{11}$.

\section{Materiały i metodyka badań}

Aby zweryfikować hipotezę badawczą, zastosowano taksonomiczny miernik rozwoju według wzoru:

$$
q_{i}^{\prime}=\mathbf{1}-\frac{q_{i}}{\bar{q}+2 S_{q}}
$$

${ }^{6}$ K. Pieńkos, K. Podleśna-Dudicz, Problemy turystyki zrównoważonej w lasach, [w:] A. Gotowt-Jeziorska, J. Śledzińska, Turystyka zrównoważona i ekoturystyka, Wydawnictwo PTTK „Kraj”, Warszawa 2008, s. 113.

${ }^{7}$ M. Kazimierczak, Turystyka zrównoważona synonimem turystyki zorientowanej etycznie, „Studia Periegetica” 2009, nr 3, s. 14.

${ }^{8}$ A. Kowalczyk, Turystyka zrównoważona - aspekty kulturowe, [w:] Z. Młynarczyk (red.), Uwarunkowania i plany rozwoju turystyki, t. VI, Bogucki Wydawnictwo Naukowe, Poznań 2010, s. 18.

9 J. Uglis, A. Jęczmyk, Agroturystyka jako faktor zrównoważonego rozwoju, „Prace Naukowe Uniwersytetu Ekonomicznego we Wrocławiu” 2015, nr 379, s. 59, DOI: 10.15611/pn.2015.379.05.

${ }^{10}$ M. Mika, Sustainable tourism: a critique of the academic feasibility of the concept, „Tourism; The Journal of University of Lodz" 2014, nr 25/1, s. 14-15, DOI: 10.2478/tour-2014-0015.

${ }^{11}$ A. Niezgoda, Obszar recepcji turystycznej w warunkach rozwoju zrównoważonego, Wydawnictwo Akademii Ekonomicznej w Poznaniu, Poznań 2006, s. 300. 
gdzie:

$q_{i}^{\prime}{ }_{i}$ - unormowana wartość zmiennej syntetycznej (TMR),

$\bar{q}$ - średnia arytmetyczna,

$S_{q}$ - odchylenie standardowe zmiennej syntetycznej.

Zdecydowano się na wybór tej metody badawczej, gdyż pozwala ona uwzględnić jednocześnie wiele zmiennych i podzielić je na stymulanty, destymulanty i nominanty. Badanie turystyki zrównoważonej musi brać pod uwagę zarówno pozytywny, jak i negatywny wpływ tej gałęzi gospodarki na środowisko i społeczeństwo, a także uwzględniać wiele czynników z różnych obszarów działalności człowieka, gdyż turystyka wpływa na rozwój regionu bezpośrednio oraz pośrednio. Ustalenie realizacji zmiennej syntetycznej nastąpiło przez policzenie odległości ekonomicznej (kwadrat odległości euklidesowej) od wzorca rozwoju. W artykule zastosowano metodę średnich zagnieżdżonych, która jest najczęściej stosowana do klasyfikacji obiektów do grup, oraz analizę skupień, gdzie wykorzystano odległość euklidesową, a województwa zostały pogrupowane metodą Warda.

W kwestii kryteriów merytorycznych doboru zmiennych brano pod uwagę stan wiedzy w obszarze nauk o turystyce i nauk ekonomicznych. Na konieczność uwzględnienia czynników związanych z przyrodniczymi walorami badanego obszaru, a także zagospodarowaniem turystycznym wskazała I.M. Batyk ${ }^{12}$, natomiast L. Butowski ${ }^{13}$ podkreślił potrzebę zwrócenia uwagi na ekonomiczne aspekty rozwoju turystyki ze względu na powiązania z koncepcją zrównoważonego rozwoju. $\mathrm{W}$ badaniu turystyki zrównoważonej na obszarach gmin województwa zachodniopomorskiego, przeprowadzonym przez B. Meyer, zastosowano zestaw zmiennych ekonomicznych, społecznych i środowiskowych ${ }^{14}$. W poniższym badaniu wykorzystano dane pochodzące z Banku Danych Lokalnych Głównego Urzędu Statystycznego oraz z raportów dotyczących turystyki, opracowanych przez GUS. Spis zmiennych wybranych do badania przedstawia się następująco:

$\mathrm{X} 1$ - dochody budżetów gmin i miast na prawach powiatu ogółem na jednego mieszkańca,

X2 - drogi publiczne ogółem w km,

X3 - liczba imprez artystyczno-rozrywkowych, interdyscyplinarnych i sportowych ogółem,

$\mathrm{X} 4$ - lesistość $\mathrm{w} \%$,

X5 - liczba nowo utworzonych miejsc pracy w tys. osób,

X6 - linie kolejowe eksploatowane w km ogółem,

$\mathrm{X} 7$ - linie regularnej komunikacji autobusowej w szt.,

${ }^{12}$ I.M. Batyk, Wybrane aspekty turystyki zrównoważonej w województwie warmińsko-mazurskim, „Infrastruktura i Ekologia Terenów Wiejskich” 2010, nr 1, s. 57-58.

${ }^{13}$ L. Butowski, op. cit., s. 11.

${ }^{14}$ B. Meyer, Funkcja turystyczna a zrównoważony rozwój obszarów nadmorskich na przykładzie gmin województwa zachodniopomorskiego, ,Prace Naukowe Uniwersytetu Ekonomicznego we Wrocławiu" 2013, nr 303, s. 172. 
X8 - placówki gastronomiczne w turystycznych obiektach noclegowych ogółem,

X9 - pomniki przyrody ogółem,

X10 - przeciętne miesięczne wynagrodzenie brutto,

X11 - ruch pasażerów w portach lotniczych - przyjazdy w szt.,

$\mathrm{X} 12$ - stopa bezrobocia rejestrowanego,

X13 - stopień wykorzystania obiektów noclegowych ogółem,

X14 - liczba kuracjuszy leczonych stacjonarnie w szt.,

X15 - udział gruntów zdewastowanych i zdegradowanych wymagających rekultywacji w powierzchni ogółem,

X16 - udział obszarów prawnie chronionych w powierzchni ogółem,

X17 - wypadki drogowe na 100 tys. ludności,

X18 - zwiedzający muzea i oddziały na 10 tys. mieszkańców,

X19 - liczba szpitali uzdrowiskowych/sanatoriów w szt.,

X20 - liczba obiektów noclegowych ogółem,

X21 - powierzchnia parków spacerowo-wypoczynkowych w miastach i na wsi w ha,

X22 - liczba turystów na 100 mieszkańców (wskaźnik intensywności ruchu turystycznego według Schneidera),

X23 - szlaki turystyczne na $100 \mathrm{~km}^{2}$ powierzchni,

X24 - miejsca noclegowe w turystycznych obiektach noclegowych,

X25 - natężenie krajowego ruchu turystycznego mieszkańców Polski w wieku 15 lat i więcej według województw.

Zmienne X12, X15 i X17 uznane zostały za destymulanty, pozostałe zaś są stymulantami. Przyjęto wagi stałe.

\section{Wyniki badań}

W tabeli 1 przedstawiono ranking województw pod względem taksonomicznego miernika rozwoju. Można zauważyć, że w roku 2015 obszarem o najbardziej zrównoważonej turystyce było województwo mazowieckie, natomiast najniższą wartość TMR przyjmował w województwie opolskim. Zwraca uwagę fakt, że wartości taksonomicznego miernika rozwoju dla poszczególnych województw różnią się znacząco. Zbliżone wartości charakteryzują jedynie województwa lubelskie i warmińsko-mazurskie, a także lubuskie i łódzkie.

$\mathrm{Z}$ tabeli 1 wynika, że województwa uznawane za popularne destynacje turystyczne (małopolskie, dolnośląskie, pomorskie, zachodniopomorskie) zajmują wysokie pozycje w rankingu (miejsca 2.-5.). Województwa podkarpackie i warmińsko-mazurskie, które są znane z atrakcyjności turystycznej, plasują się odpowiednio na miejscu 9. i 11. Miejsca od 12. do 16. zajmują regiony, które nie są powszechnie kojarzone z turystyką. W powyższym zestawieniu dziwi wysoka pozycja województw śląskiego, wielkopolskiego i kujawsko-pomorskiego. Moż- 
na wysnuć wniosek, że o wysokiej pozycji województwa kujawsko-pomorskiego zdecydowała liczba kuracjuszy i dobrze rozwinięta infrastruktura uzdrowiskowa, natomiast wysoka pozycja województwa śląskiego jest zasługą najwyższej wśród województw liczby imprez artystyczno-rozrywkowych, interdyscyplinarnych, sportowych i innych, a także dobrze rozwiniętej infrastruktury transportowej. Województwo wielkopolskie swoją wysoką pozycję zawdzięcza najniższej stopie bezrobocia rejestrowanego. Rezultat grupowania województw według wartości TMR przedstawiono na rysunku 1.

Tabela 1. Klasyfikacja województw pod względem taksonomicznego miernika rozwoju

\begin{tabular}{|r|l|c|}
\hline 1 & mazowieckie & 0,48029125 \\
\hline 2 & małopolskie & 0,43622866 \\
\hline 3 & dolnośląskie & 0,38197663 \\
\hline 4 & pomorskie & 0,37806156 \\
\hline 5 & zachodniopomorskie & 0,36476290 \\
\hline 6 & śląskie & 0,32873900 \\
\hline 7 & wielkopolskie & 0,30123132 \\
\hline 8 & kujawsko-pomorskie & 0,28386983 \\
\hline 9 & podkarpackie & 0,20794068 \\
\hline 10 & lubelskie & 0,17718524 \\
\hline 11 & warmińsko-mazurskie & 0,17180029 \\
\hline 12 & lubuskie & 0,15986518 \\
\hline 13 & łódzkie & 0,15242293 \\
\hline 14 & podlaskie & 0,13749830 \\
\hline 15 & świętokrzyskie & 0,10361248 \\
\hline 16 & opolskie & 0,05122713 \\
\hline
\end{tabular}

Źródło: opracowanie własne.

Przy klasyfikacji regionów do poszczególnych grup wykorzystano metodę średnich zagnieżdżonych. Grupa pierwsza obejmuje województwa, w których poziom wskaźnika TMR uznano za wysoki. Są to województwa: mazowieckie, pomorskie, dolnośląskie i małopolskie. Umiarkowany poziom wskaźnika (grupa 2) charakteryzuje województwa: zachodniopomorskie, kujawsko-pomorskie, wielkopolskie oraz śląskie. Województwa: warmińsko-mazurskie, lubelskie, lubuskie, łódzkie i podkarpackie zostały zakwalifikowane do grupy trzeciej, czyli poziom wskaźnika TMR na ich obszarze można określić jako niski. Bardzo niski poziom TMR występował natomiast w województwach: podlaskim, opolskim i świętokrzyskim, które zakwalifikowano do grupy czwartej.

Zgodnie z rysunkiem 1 najwyższy poziom taksonomicznego miernika rozwoju występował głównie w północno-zachodniej i południowej części Polski. Wyjątek stanowi województwo mazowieckie, w którym TMR przyjął najwyższą wartość. Ma to związek z najwyższymi wśród województw dochodami per capita, dobrą infrastrukturą transportową (w tym zlokalizowanymi w województwie dwo- 
ma lotniskami), niskim bezrobociem, najwyższą wśród województw liczbą nowo utworzonych miejsc pracy, najwyższym wśród województw poziomem wynagrodzeń brutto, wysokim wykorzystaniem miejsc noclegowych, najwyższą wśród województw liczbą zwiedzających muzea na 10 tys. mieszkańców.

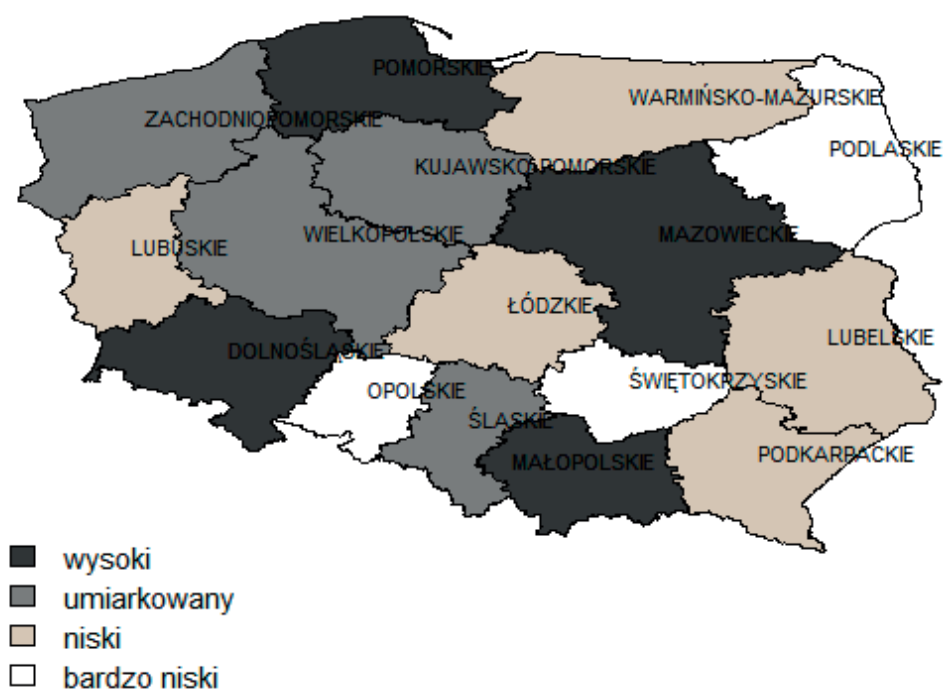

Rysunek 1. Grupowanie województw według wartości TMR w 2015 roku Źródło: opracowanie własne.

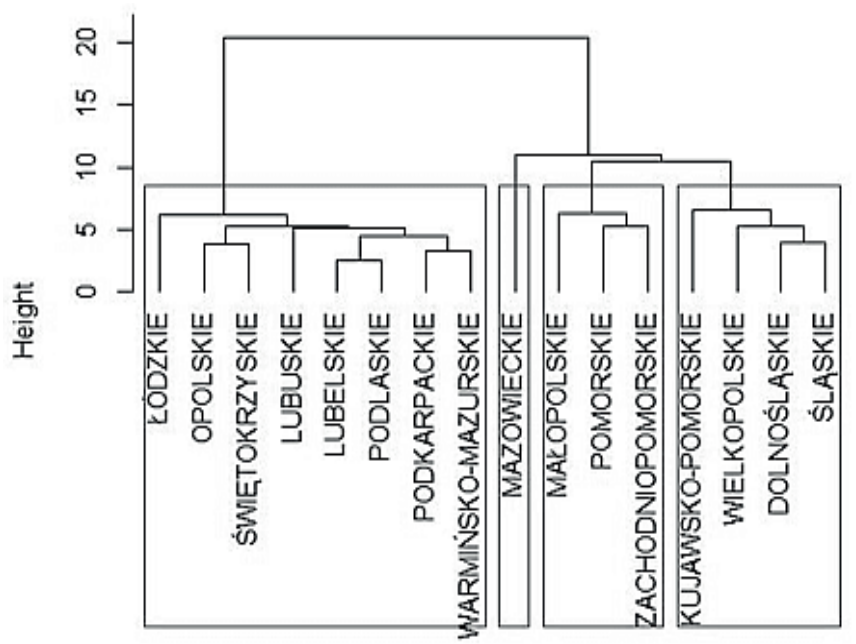

Rysunek 2. Grupowanie województw metodą Warda dla 2015 roku Źródło: opracowanie własne. 
Analizując przedstawiony na rysunku 2 dendrogram, można stwierdzić, że województwa zostały podzielone na cztery grupy, składające się odpowiednio z ośmiu, jednego, trzech i czterech elementów. W najliczniejszej, ośmioelementowej grupie jako pierwsze połączone zostały województwa lubelskie oraz podlaskie, w których większość zmiennych diagnostycznych miała zbliżony poziom. Następnie dołączono województwa: podkarpackie i warmińsko-mazurskie, które miały podobny poziom zmiennych X1, X3, X9, X10, X13 oraz X15. W dalszej kolejności przyłączone zostało województwo lubuskie, w przypadku którego spośród wymienionych wcześniej zmiennych różniła się znacznie tylko zmienna X3. Następnie dołączono województwo opolskie wraz ze świętokrzyskim, ze względu za zbliżony poziom zmiennych X1, X10, X13 oraz X11. Ostatnie do grupy dołączyło województwo łódzkie, mające podobne wartości zmiennych X10 oraz X13.

Grupa druga jest jednoelementowa i składa się wyłącznie z województwa mazowieckiego. Natomiast grupa trzecia obejmuje trzy elementy. Jako pierwsze zostały połączone województwa pomorskie i zachodniopomorskie. Podobne wartości wykazywały zmienne X1, X3, X4, X6 oraz X8. W dalszej kolejności dołączono województwo małopolskie, które wykazywało zbliżony poziom zmiennej X6.

$\mathrm{W}$ czteroelementowej grupie czwartej pierwsze skupienie dotyczyło województw śląskiego i dolnośląskiego. Było to spowodowane podobieństwem zmiennych X1, X4, X10, X12, X13, X15 oraz X16. W dalszej kolejności dołączono województwo wielkopolskie, które cechował podobny poziom zmiennych X4, X13 i X15. Ostatnie do grupy przyłączone zostało województwo kujawsko-pomorskie, które charakteryzowała zbliżona lesistość oraz dochody per capita.

Grupa trzecia i czwarta zostały połączone, a następnie dołączono do nich jednoelementową grupę drugą. Jako ostatnią dołączono grupę pierwszą. Między wspomnianymi wyżej czterema grupami występują istotne różnice. W przypadku grupy trzeciej oraz czwartej różnicujące zmienne to przede wszystkim: X4, X15, X20, X22, X24 oraz X25. Zmiennymi różnicującymi jednoelementową grupę drugą (województwo mazowieckie) od grupy trzeciej i czwartej są: X1, X2, X5, X7, X9, X10, X11, X14 oraz X20. Natomiast dysonans między grupą pierwszą a połączonymi grupami: drugą, trzecią i czwartą spowodowany jest głównie przez zmienne: X3, X8 oraz X24, ale widoczne różnice występują też w przypadku zmiennych X2, X5, X6, X7, X11, X12 oraz X25.

\section{Podsumowanie i wnioski}

W wyniku przeprowadzonego badania hipotezy: „Obszarami recepcji turystyki zrównoważonej w 2015 roku były województwa położone na północy i południu Polski" nie można uznać za potwierdzoną. Analiza przeprowadzona za pomocą taksonomicznego miernika rozwoju wykazała, że wysokie wartości wskaź- 
nika wystąpiły w województwach położonych na północnym zachodzie kraju, w jego centrum i na południu. Nie wszystkie województwa położone na północy bądź na południu Polski charakteryzowały się wysokim poziomem turystyki zrównoważonej. Taka sytuacja miała miejsce w przypadku województw: opolskiego, warmińsko-mazurskiego i podkarpackiego. Tymczasem zwłaszcza dwa ostatnie wymienione województwa są znanymi destynacjami turystycznymi. Możliwe, że niewysoki poziom wskaźnika ma związek z niedostateczną infrastrukturą transportową. $Z$ drugiej strony wysoki poziom wskaźnika TMR występował w województwie kujawsko-pomorskim, wielkopolskim i oczywiście mazowieckim, gdzie przyjmował najwyższą wartość. Te trzy województwa nie są powszechnie kojarzone z turystyką. Należy jednak zwrócić uwagę na mnogość rodzajów turystyki. Województwo mazowieckie z dużym lotniskiem oraz rozbudowaną bazą noclegową i konferencyjną jest destynacją turystyki biznesowej. Infrastruktura transportowa w pobliżu stolicy, obecność dwóch lotnisk, a także wysokie średnie wynagrodzenie brutto wraz ze znaczą liczbą nowo utworzonych miejsc pracy mogą zaciemniać rzeczywisty poziom turystyki zrównoważonej w tym województwie. Widać to na dendrogramie, gdzie mazowieckie stanowi odrębną, jednoelementową grupę. Włodarze województwa kujawsko-pomorskiego, zgodnie ze strategią rozwoju, postawili sobie za cel wspieranie turystyki uzdrowiskowej. Województwo wielkopolskie swoją wysoką pozycję zawdzięcza zaś najniższej w kraju stopie bezrobocia rejestrowanego oraz dobrej infrastrukturze transportowej.

Na podstawie przeprowadzonej analizy można wysnuć jeszcze jeden wniosek. Turystyka jest branżą, której efekty są trudne do zmierzenia. Nie wszyscy turyści korzystają z usług noclegowych w miejscach, które podlegają obowiązkowi raportowania do Głównego Urzędu Statystycznego. Podobnie jest z odwiedzalnością atrakcji turystycznych. Wiele z nich jest bezpłatnych albo nie podlega obowiązkowi raportowania. Ponieważ turyści korzystają z tej samej infrastruktury co mieszkańcy danego obszaru, trudności sprawia wyliczenie, ile generują dochodu, na przykład dla lokalnych sklepów. Jest to problematyczne zwłaszcza w tych destynacjach turystycznych, w których sezonowość nie jest wyraźna. Ponadto należy zwrócić uwagę na fakt, że koncepcja turystyki zrównoważonej jest bardzo nieścisła, co implikuje trudności w doborze właściwych zmiennych do badania oraz w określeniu ich optymalnego poziomu.

\section{Bibliografia}

Batyk I .M., Wybrane aspekty turystyki zrównoważonej w województwie warmińsko-mazurskim, „Infrastruktura i Ekologia Terenów Wiejskich” 2010, nr 1.

Butowski L., Dlugookresowy model turystyki zrównoważonej, „Zeszyty Naukowe Uczelni Vistula" 2013, nr 32.

Cegliński P., Kwestie zrównoważonego rozwoju w strategiach przedsiębiorstw, „Studia i Prace Wydziału Nauk Ekonomicznych i Zarządzania” 2015, nr 40, t. 2, DOI: 10.18276/sip.2015.40/2-02. 
Kazimierczak M., Turystyka zrównoważona synonimem turystyki zorientowanej etycznie, „Studia Periegetica" 2009, nr 3.

Kowalczyk A., Turystyka zrównoważona - aspekty kulturowe, [w:] Z. Młynarczyk (red.), Uwarunkowania i plany rozwoju turystyki, t. VI, Bogucki Wydawnictwo Naukowe, Poznań 2010.

Mastalska-Cetera B., Warczewska B., Możliwości rozwoju turystyki zrównoważonej na przykładzie dolnoślaskich parków krajobrazowych, „Prace Naukowe Uniwersytetu Ekonomicznego we Wrocławiu" 2015, nr 397.

Meyer B., Funkcja turystyczna a zrównoważony rozwój obszarów nadmorskich na przykładzie gmin województwa zachodniopomorskiego, „Prace Naukowe Uniwersytetu Ekonomicznego we Wrocławiu" 2013, nr 303.

Mika M., Przemiany pod wptywem turystyki na obszarach recepcji turystycznej, [w:] W. Kurek (red.), Turystyka, Wydawnictwo Naukowe PWN, Warszawa 2008.

Mika M., Sustainable tourism: a critique of the academic feasibility of the concept, „Tourism; The Journal of University of Lodz" 2014, nr 25/1, DOI: 10.2478/tour-2014-0015.

Naumowicz K., Podstawowe zagadnienia turystyki, http://www.academia.edu/4568029/Prof. PWSZ_dr_hab._Krystyna_Naumowicz_PODSTAWOWE_ZAGADNIENIA_TURYSTYKILITERATURA_DODATKOWA (dostęp: 11.01.2016).

Niezgoda A., Obszar recepcji turystycznej w warunkach rozwoju zrównoważonego, Wydawnictwo Akademii Ekonomicznej w Poznaniu, Poznań 2006.

Pieńkos K., Podleśna-Dudicz K., Problemy turystyki zrównoważonej w lasach, [w:] A. Gotowt-Jeziorska, J. Śledzińska, Turystyka zrównoważona i ekoturystyka, Wydawnictwo PTTK „Kraj”, Warszawa 2008.

Uglis J., Jęczmyk A., Agroturystyka jako faktor zrównoważonego rozwoju, „Prace Naukowe Uniwersytetu Ekonomicznego we Wrocławiu” 2015, nr 379, DOI: 10.15611/pn.2015.379.05.

\section{Streszczenie}

Celem artykułu jest określenie, na terenie których polskich województw turystyka najlepiej spełnia kryteria zrównoważonego rozwoju. Aby zrealizować cel badawczy, postawiono hipotezę, która brzmi: „Obszarami recepcji turystyki zrównoważonej w 2015 roku były województwa położone na północy i południu Polski”. Badanie turystyki zrównoważonej musi brać pod uwagę zarówno pozytywny, jak i negatywny wpływ tej gałęzi gospodarki na środowisko i społeczeństwo, dlatego aby zweryfikować hipotezę badawczą, zastosowano taksonomiczny miernik rozwoju. W badaniu uwzględniono zmienne stricte dotyczące turystyki oraz te związane pośrednio z jej rozwojem na danym terenie. W kwestii kryteriów merytorycznych doboru zmiennych brano pod uwagę stan wiedzy w obszarze nauk o turystyce i nauk ekonomicznych. Przeprowadzona analiza wykazała, że część polskich województw może zostać uznana za obszary recepcji turystyki zrównoważonej.

Słowa kluczowe: turystyka zrównoważona, turystyka w Polsce, regiony recepcji turystycznej, taksonomiczny miernik rozwoju

Klasyfikacja JEL: C38, Q01, Z32 